IZA DP No. 6871

Miserable Migrants? Natural Experiment Evidence

on International Migration and Objective and

Subjective Well-Being

Steven Stillman

John Gibson

David McKenzie

Halahingano Rohorua

September 2012 


\title{
Miserable Migrants? Natural Experiment Evidence on International Migration and Objective and Subjective Well-Being
}

\author{
Steven Stillman \\ University of Otago and IZA \\ John Gibson \\ University of Waikato
}

David McKenzie

World Bank and IZA

Halahingano Rohorua
University of Waikato

\section{Discussion Paper No. 6871 \\ September 2012}

\author{
IZA \\ P.O. Box 7240 \\ 53072 Bonn \\ Germany \\ Phone: +49-228-3894-0 \\ Fax: +49-228-3894-180 \\ E-mail: iza@iza.org
}

\begin{abstract}
Any opinions expressed here are those of the author(s) and not those of IZA. Research published in this series may include views on policy, but the institute itself takes no institutional policy positions. The IZA research network is committed to the IZA Guiding Principles of Research Integrity.

The Institute for the Study of Labor (IZA) in Bonn is a local and virtual international research center and a place of communication between science, politics and business. IZA is an independent nonprofit organization supported by Deutsche Post Foundation. The center is associated with the University of Bonn and offers a stimulating research environment through its international network, workshops and conferences, data service, project support, research visits and doctoral program. IZA engages in (i) original and internationally competitive research in all fields of labor economics, (ii) development of policy concepts, and (iii) dissemination of research results and concepts to the interested public.
\end{abstract}

IZA Discussion Papers often represent preliminary work and are circulated to encourage discussion. Citation of such a paper should account for its provisional character. A revised version may be available directly from the author. 


\title{
ABSTRACT \\ Miserable Migrants? Natural Experiment Evidence on International Migration and Objective and Subjective Well-Being *
}

\begin{abstract}
Over 200 million people worldwide live outside their country of birth and typically experience large gains in material well-being by moving to where incomes are higher. But effects of migration on subjective well-being are less clear, with some studies suggesting that migrants are miserable in their new locations. Observational studies are potentially biased by the selfselection of migrants so a natural experiment is used to compare successful and unsuccessful applicants to a migration lottery in order to experimentally estimate the impact of migration on objective and subjective well-being. The results show that international migration brings large improvements in objective well-being, in terms of incomes and expenditures. Impacts on subjective well-being are complex, with mental health improving but happiness declining, self-rated welfare rising if viewed retrospectively but static if viewed experimentally, self-rated social respect rising retrospectively but falling experimentally and subjective income adequacy rising. We further show that these changes would not be predicted from cross-sectional regressions on the correlates of subjective well-being in either Tonga or New Zealand. More broadly, our results highlight the difficulties of measuring changes in subjective well-being when reference frames change, as likely occurs with migration.
\end{abstract}

JEL Classification: $\quad$ I31, J61

Keywords: immigration, lottery, natural experiment, subjective well-being, Tonga, Pacific Islands

Corresponding author:

Steven Stillman

Department of Economics

University of Otago

PO Box 56

Dunedin, 9054

New Zealand

E-mail: steven.stillman@otago.ac.nz

\footnotetext{
" We thank the Government of the Kingdom of Tonga for permission to conduct the survey there, the New Zealand Ministry of Business, Innovation and Employment Labour and Immigration Research Centre for providing the sampling frame, audiences at the ABCDE, ADEW, ESPE, LEW, WEAI and AFD/DEGRG/CGD Migration and Development conferences for helpful comments and most especially the study participants. Financial support from the World Bank, Stanford University, the Waikato Management School and Marsden Fund grant UOW0503 is gratefully acknowledged. The views expressed here are those of the authors alone and do not necessarily reflect the opinions of the World Bank, the New Zealand Ministry of Business, Innovation and Employment or the Government of Tonga.
} 


\section{INTRODUCTION}

Over 200 million people worldwide live outside their country of birth, with most having moved from a developing to a developed country. Even more move internally; for example, the current shift from rural to urban China is the largest migration flow in history (Zhao, 1999). Both international and internal migrants generally experience large gains in material well-being by moving to where incomes are higher. Yet, studies of the happiness and subjective well-being of migrants, both internal and international, suggest that they can be unhappy and dissatisfied (Safi, 2009; Knight and Gunatilaka, 2010; Bartram, 2011). Even the World Health Organization (2001) suggests that migration usually does not bring improved social well-being and instead may result in increased risk of mental disorders.

The logic of revealed preference suggests that migration should, on average, make migrants better off in the long run. Moreover, migration restrictions are some of the lowest hanging fruit for raising global prosperity. Previous study of the migrants examined in this paper shows that an adult leaving a developing country with per capita income of about US\$4000 (PPP, similar to Indonesia) and moving to one of the poorer developed countries experiences an immediate increase in earned income of 263 percent (McKenzie, Gibson and Stillman, 2010). This earnings wedge is far larger than most international price wedges on goods and capital, making immigration restrictions one of the largest distortions in the global economy (Clemens, Montenegro, and Pritchett 2008). Thus, the evidence of miserable migrants is challenging, especially because it might be used to justify continued restrictions on labor mobility as, seemingly perversely, improving happiness (Bartram, 2010).

The claimed reason for migrant unhappiness is that even though they have rising absolute incomes they face falling relative incomes, since they typically move from poorer to richer areas. If income of others enters utility functions, and if migrants experience a fall in relative position as their reference group switches from origin areas to the richer destination, 
unhappiness results (Knight and Gunatilaka, 2012). For example, many of the migrants studied here left jobs as nurses, teachers, and public servants, which placed them at the 73rd percentile of earnings in the home country. Initial occupations in the destination country had much lower status, working as farmhands, janitors, and laborers which paid only 75 percent of the destination country median wage. Even a slight recovery in occupational status when the migrants were observed three years later still saw them much lower in the income rank than in their home country, despite absolute levels of per capita income rising by more than 300 percent.

However, most of the research that lies behind claims of miserable migrants is not backed by research designs that deliver reliable answers to the question: "what is the impact of migration on well-being?" In this paper, we use unique survey data on successful and unsuccessful applicants to a migration lottery to experimentally estimate the impact of migration on objective and subjective well-being. Hence, we are able to deal with the selection bias that undermines previous studies. We also report non-experimental findings for subjective well-being, which differ from the experimental results. Our results call into question the view that migration means misery. Instead, we find complex effects of migration, with mental health improving but happiness declining, self-rated welfare rising if viewed retrospectively but static if viewed experimentally, self-rated social respect rising retrospectively but falling experimentally and subjective income adequacy rising. These complex changes in subjective well-being contrast with uniformly large improvements in objective measures such as incomes and expenditures.

A further feature of the analysis is that we observe the migrants one year and four years after they leave their Pacific Island home country of Tonga. This lag may matter since Di Tella et al. (2010) find that life satisfaction adapts completely to income changes within four years. Thus, by that timetable, at the time of our second observation, aspirations should 
have caught up to migrants' higher income and they may feel no better off than before they moved. A final feature of our study is that it relies on several variables to indicate subjective well-being over different domains, whereas many studies use just a single indicator of either happiness or life satisfaction. The complexity of results we find for different subjective wellbeing indicators suggests that it may be unwise to rely on single indicator studies.

The next section briefly summarizes the findings of existing literature, where we focus on migration and subjective well-being since studies of impacts of migration on material well-being are well known (see, for example, McKenzie et al., 2010). Section 3 provides background on the migration flow we study, the migration lottery, and the survey. Section 4 reports the experimental estimates of the impacts of migration on various indicators of well-being, while Section 5 reports non-experimental estimates. Section 6 discusses external validity and Section 7 contains the conclusions.

\section{PREVIOUS LITERATURE}

Academic literature in several fields suggests that migrants are dissatisfied with their lives. A sociologist, Nirna Safi (2009, p.160) summarizes assimilation studies as showing that "migration and establishment in a new country go together with sorrow, melancholy, and despair" (p.160). Another sociologist suggests "some findings of happiness research can be used to derive the implication that migration might make some immigrants less happy than if they had stayed put" (Bartram, 2010, p.2). The reason is that even as migrants' absolute incomes rise, their relative position falls as their reference group comes to include those in the destination country, and lower relative income leads to unhappiness (Bartram, 2011). Even some economists make such claims. For example, Knight and Gunatilaka (2012) suggest rural-to-urban migration in China "may well have had the unexpected consequences of reducing subjective well-being" (p.108) because migrants' aspirations rose faster than incomes, leading to frustration and unhappiness. 
Many of these claims are not backed up by research designs that deliver reliable answers to the question: "what is the impact of migration on subjective well-being?" To answer this requires either a combination of pre- and post-migration observations on the same persons, or else matched data from the same survey applied to migrants, and a counterfactual group of non-migrants from the source area. Moreover, the counterfactual sample has to validly represent what would have happened to the migrants in the absence of migration, so there should be no self-selection bias. The literature does not appear to meet these requirements, with no study using either matched counterfactual groups formed across national borders or pre- and post-migration information on subjective well-being to examine the changes caused by migration. ${ }^{1}$ Thus, according to Bartram (2011, p.10) existing research “can't answer that longitudinal question [how migrants' well-being changed after migrating] with the cross-sectional data available".

Instead, some studies compare samples of immigrants with the native population in the host country. For example, Safi (2009) uses data from a 10-point scale on life satisfaction in the European Social Survey to compare immigrants to the native born in 13 European countries. The author claims that "being a first generation migrant reduces life satisfaction in the majority of countries" (p.167, our emphasis). But, evidence of the gap between life satisfaction scores for immigrants and the native born is irrelevant to this conclusion. Similarly, Bartram (2011) uses a 10-point life satisfaction question from the World Values Study to compare immigrants to natives in the U.S. and finds that immigrants have lower life satisfaction; such a comparison is, again, uninformative about the causal impact of migration.

There are many other studies in this literature where happiness (or other subjective well-being indicators) is compared across groups defined by migration status, in uninformative ways for finding causal impacts of migration. For example, Amit and Litwin (2010) compare migrants from different origins in the same destination, Graham and 
Markowitz (2011) compare potential emigrants with other Latin Americans who declare no intention to emigrate, and Cardenas, Di Maro and Sorkin (2009) compare life satisfaction for left behind members of households that sent migrants from Latin America with that of people in households that did not send emigrants. Similarly, Borraz, Pozo and Rossi (2010) use Propensity Score Matching (PSM) to compare happiness of left behind members to that of people in non-emigrant households in Ecuador; while this study at least attempts to form counterfactual groups there are doubts about the identification strategy since PSM can only deal with selection on observables.

Common to all of these studies is that they rely on comparisons within a single country, because the complexity of jointly surveying emigrant sources and immigrant destinations makes the needed cross-border data almost nonexistent. For this reason, the majority of evidence used by economists to study impacts of migration on subjective wellbeing comes from rural-to-urban migration, most especially within China (Knight and Gunatilaka, 2010; Akay, Bargain and Zimmermann, 2012). This evidence is widely cited, so even though it is for internal rather than international migration, we briefly review it here especially because the identification issues that weaken international migration studies are also present.

In a series of papers, Knight and Gunatilaka (2010, 2010a, 2012) use a non-random sample of urban migrants and representative samples of rural and urban residents (with hukou status) who were asked "how happy are you nowadays?" with answers on a 5-point scale. Migrant happiness scores were less those of rural residents despite their income being 2.4 times higher. The authors inferred that aspirations had risen by more than absolute incomes, causing frustration and unhappiness for the migrants. Knight and Gunatilaka (2010) consider if migrant self-selection could account for this pattern but the techniques they use (Oaxaca decompositions and added residual tests) do not address selection on unobservables, which is 
the major concern in empirical migration studies. Akay et al. (2012) use the more detailed GHQ-12 (General Health Questionnaire) to compare rural, migrant and urban households, but their cross-sectional regressions lack any way of controlling for self-selection bias. Instead, they argue that the scale of rural-to-urban migration in China, accounting for up to 18 percent of the population, makes selection bias a second order problem. However, there is strong evidence from other studies counter to this claim; for example, selection bias remains important in Mexico-US migration, despite more than ten percent of the Mexican population emigrating, and McKenzie et al. (2010) show large selection biases in estimated migration impacts from a country where more than 30 percent of the population have emigrated.

Our review of the literature suggests that many of the research designs that have been used lack valid counterfactuals of what would have happened to migrants if they had not moved. Typically, the comparisons made cannot reveal causal impacts - since migrants are compared to natives at the destination or to non-migrants in the home area without a plausible mechanism to deal with self-selection. In order to answer the question of whether migration causes subjective well-being to rise or fall, a new approach, not previously used in this literature, is needed. In the next section, we document our unique survey which provides this more reliable evidence.

\section{CONTEXT AND SURVEY}

Our analysis is of the impact that migration from Tonga to New Zealand has on the wellbeing of immigrants. Since this migration flow is not well known outside of the two countries involved, we here provide some background and context. The Kingdom of Tonga is an archipelago of islands in the Pacific, about three hours north of New Zealand by airplane. The resident population of Tonga is just over 100,000 , with a GDP per capita of US\$3,700 in PPP terms, which is similar to Indonesia and ranks $120^{\text {th }}$ out of 180 countries. ${ }^{2}$ Tonga ranks higher in the Human Development Index (at $99^{\text {th }}$, just ahead of Jamaica) because life expectancy 
(71.7 years, the same as Turkey), adult literacy (99.2\%, the same as Moldova) and the school enrolment rate (78\%, the same as Lebanon) all rank Tonga higher than on income. Hence, Tonga appears to be a setting where basic needs have already been met, which, according to Graham (2008, p.77), is the threshold beyond which "relative rather than absolute levels [of income] matter to well-being".

Emigration out of Tonga is high, with 30,000 Tongan-born living abroad, mainly in New Zealand, Australia and the United States. Despite an earlier history of employment migration to New Zealand from Tonga, family reunification (mostly marriage) was the main channel of access in the 1990s following New Zealand's implementation of a points-based immigration system which favors skilled migrants. In 2002, New Zealand introduced a new migration program, the Pacific Access Category (PAC), which allows for a quota of an additional 250 Tongans to permanently immigrate each year.

The PAC has the unique selection mechanism that we use to estimate migration impacts purged of selectivity bias, so we describe it briefly here. Any Tongan citizens aged 18 to 45 who meet certain English, health and character requirements can register to migrate to New Zealand. A random ballot selects amongst applicants, with odds of about $10 \%$ during the 2002-05 ballot years that our sample is drawn from. If their ballot is selected, applicants have six months to obtain a full-time job offer in New Zealand that meets an income threshold similar to the minimum wage. This ensures self-reliance since Tongan immigrants are not eligible for most forms of welfare assistance until they have resided in New Zealand for two years. Since 2005, married applicants can aggregate earnings with their partner to meet this threshold. After a job offer is filed along with a residence application, it typically takes from three to nine months to receive residence approval and immigration to New Zealand must then occur within 12 months. ${ }^{3}$ Spouses and any unmarried children up to age 24 are also eligible to immigrate. 
The destination for the PAC migrants, New Zealand, has higher levels than Tonga for all the material welfare components described above, but especially for income. While New Zealand is one of the poorest developed countries, with a GDP per capita of just US\$27,300 that ranks it $32^{\text {nd }}$ in the world, this is more than five times higher than in Tonga. While life expectancy and educational attainment are also higher than in Tonga, the gap is not nearly as large as for income. Hence, migration offers access to higher material living conditions, but most especially in the income dimension.

Immigrants are a large and growing share of the New Zealand population, with Tongans and other Pacific Islanders prominent in this trend. ${ }^{4}$ There are also high rates of inter-marriage of Pacific Islanders with both the indigenous Maori and the majority European population. For example, over one-half of all Pacific children in New Zealand have at least one other ethnicity, due to this high rate of out-marriage (Spoonley and Didham, 2008). This assimilation, the absence of return migration (just one sampled migrant returned in four years), and the low rate of expected future return, ${ }^{5}$ make it very likely that the reference group that Tongan migrants have in mind when answering subjective well-being questions comes from their new surroundings, and not from their previous lives in Tonga.

\section{(a) Survey data}

The data used in this paper are from the first two waves of the Pacific Island-New Zealand Migration Survey (PINZMS); a comprehensive survey designed to measure multiple impacts of migration, taking advantage of the natural experiment provided by the PAC. The survey has been overseen by the authors since its inception and operates in both New Zealand and Tonga.

The first wave of the survey in New Zealand in 2005 covered a random sample of 101 of the 302 Tongan households that migrated as successful participants in the 2002-05 PAC ballots. ${ }^{6}$ The second wave was fielded in 2008 and re-interviewed 89 of these households. Of 
the remaining households, ten had either re-migrated to a third destination country or moved to outer areas of New Zealand where it was too expensive to travel for fieldwork, while there was one refusal and one non-contact. ${ }^{7}$ At the time of the first wave of the survey, migrants had spent an average of 11 months in New Zealand. The second wave was fielded approximately 33 months later.

Fieldwork in Tonga occurred in the same years as the survey waves in New Zealand, using the same survey instrument and lead interviewer. Four groups of households were initially surveyed: a control group of households with member(s) holding unsuccessful PAC ballots, who provide counterfactual estimates of the well-being that migrants would have if they not migrated $(\mathrm{n}=124)$; a non-complier group of households with member(s) holding successful PAC ballots but still in Tonga at the time of the survey $(n=29) ;^{8}$ a group of remaining family in the same dwelling the PAC migrants had previously lived in, who did not meet relationship rules for moving to New Zealand ( $n=61$ ); and a group of non-applicants to the PAC ballots $(n=116)$. Family members left behind are excluded from all analysis in this paper and non-applicants are only used in our non-experimental analysis. In 2008, 75 of the control group households and 21 of the non-compliers were resurveyed in Tonga. ${ }^{9}$

In this paper, we focus on outcomes at either the household level (income, expenditure) or those collected from the Principal Applicant (wages, all subjective well-being measures), who is the individual who applied to the PAC. In migrant households, the Principal Applicant (PA) is well defined (i.e. there is one PA in each household and this is consistently reported across waves), but in the non-complier and unsuccessful households this is not always the case. Since, our main analysis examines outcomes cross-sectionally in waves 1 and 2, we used an algorithm to identify the likely PA in each household separately by survey wave. Hence, the balanced panel of PAs that we examine as a robustness test and in some non-experimental regressions has less individuals than in the wave 2 sample. 
The random lottery should ensure that characteristics of the ballot winners and losers are the same on average, but since we do not have data for the entire population of ballot applicants we need to check that randomization holds in our sample. Table 1 compares the means of ex-ante characteristics for PA ballot winners and ballot losers in our sample. These descriptive statistics, and all subsequent analyses, use sampling weights since the two samples of successful ballots have a higher sampling rate than the sample of unsuccessful ballots.

The ballot winners (including non-compliers who remain in Tonga) and ballot losers have largely the same average values for the ex-ante characteristics we observe. In particular, they have the same average age, birth location, education, gender, height, and personal and household income in the year prior to when most migrants left Tonga. But, the ballot winners had higher previous employment rates and a higher rate of visiting New Zealand, on average, than did the ballot losers at the time of the first wave of the survey. In the second wave of the survey, and also in the balanced panel, there was also a difference in height between the samples of ballot winners and losers. Thus, in the experimental estimates below, we will report results both without controls and then with the full set of controls (the variables in Table 1) to adjust for any differences in well-being arising from baseline differences in observed variables.

\section{(b) Measuring objective and subjective well-being}

In both waves of the survey, each adult in the household was asked about their pre-tax earnings in the previous week from all employment, and also about their usual weekly earnings and if last week earnings were atypical. These data allow us to construct our first objective measure of well-being, the weekly wage of the principal applicant, whether in Tonga or in New Zealand. These wages, and other monetary values reported below, are converted to New Zealand dollars (in June 2006 prices) at the market exchange rate that best 
matches the interview month, which matches closely with a PPP exchange rate calculated from prices we collected in both countries (McKenzie et al., 2010). ${ }^{10}$

The earnings data for all adults are also part of the household annual income variable. The other income components are net returns from sales of food crops, fish, livestock, tapa cloth and mats (from household reports on an average month), income from investments, pensions, and rentals (from household reports for the previous fortnight), and imputed values for own-produced or own-captured food consumed by the household (from reports for the previous week). The final component of the household income variable is net remittances, which are captured with an annual recall that allows for flows in both directions of both money and goods. The format of the questions for all income components was the same in both Tonga and New Zealand, and was maintained for both waves of the survey.

The second wave survey included a recall of household's typical spending in a week (for groceries, food, other daily needs), month (for housing-related costs, health expenses, transport and communication) or six months (for all other expenditures). We use the log of total household expenditures and the share of food (both including imputed values for ownproduced or own-captured food consumed by the household) in total expenditures as objective measures of welfare. Since household size can change with migration, and also over time, we estimate the income and expenditure impacts of migration at both the household level and in per capita terms.

In terms of subjective well-being, in both waves of the survey every adult in the household was asked:

During the past month, how much of the time were you a happy person?

Responses are on a 5-point scale that ranges from "all of the time" to "none of the time". This is one of five questions for the Mental Health Inventory 5 (MHI-5) of Veit and Ware (1983). ${ }^{11}$ The other questions for calm and peacefulness, being downhearted, cheerfulness 
and nervousness also are scored on the same 5-point scale. Thus, the MHI-5 score has a maximum value of 25 , for the best mental health, and a minimum value of 5. Large positive impacts on the overall MHI-5 after migrating from Tonga to New Zealand have previously been found (Stillman et al. 2009). In the current analysis, we show the happiness score (on a 1-5 scale) for PAs separately from the subtotal of their other four components (on a 4-20 scale).

The remaining subjective well-being questions were only included in wave 2 , where the PA was asked to place themselves on Cantril (1965) ladders. First, the survey asked:

"Please imagine a 10-step ladder where on the bottom, the first step, stand the poorest people, and on the highest step, the tenth, stand the rich. On which step are you today?"

Our wording of the question follows Lokshin and Ravallion (2005), who call this the Welfare Ladder Question (WLQ). ${ }^{12}$ This question has been shown by Ravallion and Lokshin (2002) to capture a much broader concept of welfare than just income, even if the use of "poor" and "rich" gives respondents a narrower focus than the 'ladder of life' questions often used in psychometric surveys. Since we already had information on happiness, having separate questions directed at various other domains of subjective well-being was considered better than asking one encompassing question on either happiness or life satisfaction (Nielsen et al., 2010).

For assessing self-rated respect, the survey asked:

"And now please imagine another 10-step ladder, where on the lowest step are people who are absolutely not respected and on the highest step stand those who are very respected. On which step of this ladder are you today?"

We refer to this as the Respect Ladder Question (RLQ). The WLQ and the RLQ were addressed to respondents in both Tonga and New Zealand. Additionally, the migrants in New Zealand were asked about the step on the welfare ladder and respect ladder that they were on when last living in Tonga. Therefore, we have two counterfactuals for what would have been 
the subjective well-being of the migrants if they had not left Tonga - their retrospective report of what was their well-being before they left, and the contemporaneous level of wellbeing of a statistically valid control group of non-migrants whose composition is determined by lottery.

The final subjective well-being question is an income adequacy question that was asked of a single adult respondent in each household in New Zealand and Tonga:

"Thinking about all of your CASH income in New Zealand (Tonga), from wages and business, selling things and other sources, how well does your total income meet your everyday needs for things such as food, clothing, church and other necessities?"

Respondents could report having "not enough money", "just enough money" "enough money" or "more than enough money". Since this question was asked in a survey module on remittance channels and the household's use of the financial system, the respondent would normally be either the household head or the person who made major financial decisions for the household and this is most likely to be the Principal Applicant. We code this variable on a 1-4 scale for our analysis.

\section{EXPERIMENTAL RESULTS}

We are interested in the impact of migration on objective and subjective well-being (W). To deal with self-selection bias, we rely on the PAC lottery randomly choosing a subset of households who become eligible to migrate from a larger pool of households interested in migrating. In the absence of non-compliance to the migration treatment, all that is needed is the simple experimental estimator of the treatment effect on the treated (SEE-TT). This is the difference in mean well-being between the lottery winners who migrate and the unsuccessful ballots:

$$
\text { SEE }-T T=\bar{W}_{\text {Migrants }}-\bar{W}_{\text {Ballot losers }}
$$

But, as seen in Table 1, 15 percent of PA ballot winners have not moved to New Zealand at the time of our wave 1 survey - in part because they could not meet some 
requirements of the policy, such as finding a job offer. Therefore, we employ the standard technique of using assignment to treatment (winning the PAC ballot) as an instrumental variable for the actual treatment of migrating in order to deal with this non-compliance (Angrist, Imbens and Rubin, 1996). Since there is no substitution (that is, ballot losers migrating through other means), the local average treatment effect (LATE) coming from the IV estimates is equal to the average treatment effect on the treated (Angrist, 2004). Hence, the debate in the development literature about the value of LATE estimates (Deaton, 2009) is not relevant to the discussion here as all migrants observed in wave 1 enter New Zealand via the PAC lottery.

In order to improve the precision of the IV estimates, we also include control variables for observable pre-existing characteristics of PA ballot winners and losers. To deal with potential attrition bias from not managing to re-interview everyone from wave 1, we also report results for the balanced panel where the same PA was observed in both waves of the survey. Thus, the following tables that report the experiment estimates have three sets of results; the first presents IV estimates for the full sample with no control variables, followed by full sample results with control variables (those listed in Table 1) and then for the balanced panel with control variables. In order to provide a sense of the relative magnitude of the impacts, the mean of each outcome measure for the control group sample of unsuccessful ballots is also reported.

\section{(a) Impacts on objective well-being}

Very large gains in objective well-being result from migrating to New Zealand (Table 2). The weekly wage of principal applicants rose by NZ\$321 (US\$200) within a year of first moving which is almost three times the weekly wages of the control group in Tonga (NZ\$117). Introducing the control variables and restricting the sample to the balanced panel causes only a small reduction in the estimated initial impact. The impact of migration on wages was about 
one-quarter larger by the time of the second wave of the survey, three years later. By this stage, the control group members in Tonga had real wages (in NZD terms) that had fallen slightly, likely due to a recession in Tonga that saw real GDP almost five percent below its level from three years earlier, so the wage impact at wave 2 for the migrants is almost four times as large as the counterfactual wage they would have earned in Tonga. The lower rows in Table 2 show that estimated impacts with the full set of control variables and with the balanced panel are about 90 percent of those from just the simple IV regression of wages on the migration dummy. Thus, there do not seem to be threats to the validity of these estimates from either imperfect initial sampling or incomplete follow-up in the wave 2 survey. ${ }^{13}$

The household income of migrants doubled within the first year of moving to New Zealand. ${ }^{14}$ The impact on per capita household income was lower, at about 60 percent, because employment rates initially fell for the secondary migrants accompanying the principal applicant. Moreover, many of the migrants initially moved in with extended family members while they were establishing in New Zealand so household size relative to the number of income-earning members rose compared with in Tonga. But, by the time of the wave 2 survey, all of the migrants had transitioned into their own accommodation, with average household size lower than in Tonga because the eligibility restrictions prevented extended family co-residents from migrating with the Principal Applicant. Consequently, in wave 2, the per capita estimates of impacts exceed the household-level estimates. Even for the results with control variables and restricting attention to the balanced panel, the wave 2 income effects are very large; total household income had risen by 297 percent due to migration while per capita income was 340 percent higher.

The final results in Table 2 are for total expenditures and the food share of expenditures, both of which are used as indicators of permanent income effects. The estimated impacts of migration on household and per capita expenditure are smaller in 
magnitude than the impacts on income, as would be predicted by the permanent income hypothesis, but are still extremely large in magnitude with a $214-231 \%$ increase in household expenditure and a $237-259 \%$ increase in household expenditure per capita. Similarly, the fall in the food share of total expenditures, by over 47 percentage points, indicates a large positive improvement in real incomes for the migrant households.

\section{(b) Impacts on subjective well-being}

Table 3 reports the impact of migration on the happiness of migrant principal applicants, on the other components of their MHI-5 and on the welfare and respect ladders and income adequacy. The results in the first column show the short-term effects of migration are to leave happiness unchanged. However, the other components of mental health rise significantly, with an average treatment effect of about 1.8 points; equivalent to about one standard deviation. This divergence between components of mental health suggests that a focus just on happiness may miss some broader improvements in psychological well-being brought about by migration.

The results from wave 2 (in columns 3 and 4) show that the divergence in impacts on happiness versus other mental health components increases over time. The happiness scores of migrants are approximately 0.8 points lower than they would have been in Tonga, about four years after migrating. This finding might be taken as evidence for claims in the literature that migration may make immigrants less happy than if they had stayed put (Bartram, 2010). But that interpretation is weakened by the very substantial rise in the other components of mental health, of about three points, which is equivalent to one quarter of the wave 2 scores for the control group in Tonga. Putting happiness back in with the other mental health components, the overall MHI-5 score of migrants in wave 2 is at least two points higher than it would have been if they had stayed in Tonga; this significant improvement in mental health 
shows that the short-term gains noted by Stillman et al., (2009) are not just a transitory effect of migration.

The results for the remaining subjective well-being indicators that are measured by the survey - the welfare ladder, the respect ladder and income adequacy - also show a diversity of impacts of migration. There is no impact of migration on the migrants' position on the welfare ladder, but they go down about 0.9 steps on the respect ladder (equivalent to a drop of about one-eighth of the mean score for the control group in Tonga). Conversely, selfrated income adequacy goes up by at least 0.2 points with migration, which is equivalent to about one-tenth of the mean score for the control group. None of these patterns or magnitudes changes if the control variables are used or if the sample is restricted to the balanced panel of principal applicants. Thus, in contrast to the consistently large and positive impacts of migration on objective well-being, there are more subtle and complex effects on subjective well-being with some indicators improving, others static, and happiness and respect falling.

\section{NON-EXPERIMENTAL RESULTS}

The randomization provided by using a lottery to determine which Tongans can apply to immigrate to New Zealand provides a rare opportunity to experimentally estimate impacts of migration on objective and subjective well-being. Other studies typically use nonexperimental methods to construct the no-migration counterfactuals needed for estimating impacts, by either retrospectively asking migrants about their pre-migration outcomes or by comparing migrants to other groups in either source or destination areas. In this section, we examine how the results obtained using some non-experimental approaches compare to the experimental estimates. Since this sort of exercise has already been conducted for objective well-being outcomes with the PINZMS data (McKenzie et al., 2010), we concentrate here on the subjective well-being indicators. 
Subjective well-being appears to rise for migrants when their current position on either the welfare or respect ladder is compared with their retrospective report of where they were on the ladder when last living in Tonga. Men report an increase of three-quarters of a step on the welfare ladder and two-thirds of a step on the respect ladder, while women report two-thirds of a step increase in welfare and no increase in respect (Table 4). The larger gains for men than for women may reflect the wage gains that Tongan men experienced relative to the wages they expected whereas women had reasonably accurate wage expectations (McKenzie et al., 2013). In fact, when regressions for the change in ladder step are estimated separately for women and men, with changes in employment status and labor earnings as explanatory variables, it appears that changes in labor market outcomes may explain some of the ladder changes (employment for men's WLQ and wages for women's RLQ).

The results in Table 4 contrast with the inferences that came from experimental estimates of the impacts of migration on welfare and respect in Table 3. Compared with the control group in Tonga, respect was significantly lower for the migrants while their welfare ladder position was unchanged. One hypothesis about the source of this discrepancy between experimental and non-experimental results is that retrospective reports may reflect a filtering of past memories, where previous life in Tonga is reevaluated from the reference point of subjective well-being as experienced in New Zealand. The migrants appear to perceive that they are better off than they were in Tonga, but rather than that taking the form of advancing up a subjective ladder they instead demote their previous position. To the extent that this sort of filtering may occur more widely when frames of reference change, retrospective questions about changes in subjective well-being may be an unreliable guide to actual changes.

Next, we examine the relationship between both absolute and relative employment outcomes in Tonga (Table 5) and New Zealand (Table 6) and each measure of subjective well-being. In both tables, we examine these relationships both cross-sectionally and, for 
happiness and mental health which are measured in both wave 1 and 2, including individual fixed effects. When we examine these relationships in Tonga, we use our entire sample including non-applicants, while the analysis for New Zealand only includes successful migrants.

In Tonga, we find no evidence that happiness, residual mental health or income adequacy are related to absolute levels of labor earnings. Interesting, conditional on absolute earnings levels, Tongans who are higher up in the earnings distribution are slightly more happy but have lower residual mental health. However, this is only true cross-sectionally and the effect size is quite small with a 10 percentile move in the distribution leading to a 0.1 point increase in happiness and a 0.3 point decrease in residual mental health. Perhaps reassuringly, higher levels of labor earnings are strongly correlated with higher reported RLQ and WLQ.

Among migrants in New Zealand, labor earnings are only related to reported income adequacy, with individuals with higher earnings reporting greater income adequacy, but controlling for this, those in a higher position in the earnings distribution among all migrants in New Zealand from the Pacific Islands reporting lower income adequacy. This second finding is consistent with the idea that people adjust their expectations to match those of their peer group, but only appears to be true in this sample for this one particular measure of subjective well-being. Overall, these results from both Tonga and New Zealand are not generally consistent with our experimental findings of large increases in labor earnings, declines in happiness and respect, increases in residual mental health and income adequacy and no change in subjective welfare.

\section{EXTERNAL VALIDITY AND GENERALIZABILITY}

Evidence from natural experiments has good internal validity, due to the randomization, which is not always matched by equally good external validity. Instead, results are from a 
specific context - in this case the lottery-based migration of Tongans to New Zealand - and there can be doubts that this context will generalize to other settings of interest. But the type of work-based migration from a developing to a developed country studied here is of substantial and growing importance. Özden et al. (2011, p.15) note that “...origin countries most affected by international migration are small, typically island states, mostly in the Pacific or the Caribbean. The destination countries most affected by migration are the countries of the New World (the United States, Canada, Australia, and New Zealand)...”. Hence, the context studied here is the right one to see impacts of international migration on subjective and objective well-being since it focuses on an origin-destination comparison which is typical of the main international migration corridors.

Another reason for broader interest in the findings of the current study is because of the low evidentiary standard in the extant literature on immigration and subjective wellbeing. Most research designs lack valid counterfactuals of what would have happened to migrants if they had not moved, and typically make comparisons that cannot reveal causal impacts - such as of migrants to natives at the destination or of migrants to non-migrants in the home area without a plausible mechanism for dealing with migrant self-selection. Moreover, existing studies rely on a single indicator, such as happiness or life satisfaction, yet our results show that various indicators of subjective well-being may not move in parallel so there is no single sufficient statistic to capture changes in well-being following a major event like migration. ${ }^{15}$ Even more troubling is the finding that retrospective counterfactuals are unlikely to match experimental counterfactuals because of the apparent reinterpretation of the past from migrants adopting a more worldly scale when they move to large urban areas. Since retrospective questions would be feasible for all research designs, evidence on the potential weakness of this approach should be of broad interest. 


\section{CONCLUSIONS}

A growing literature on the subjective well-being of migrants suggests that even though there may be gains in material well-being by moving to where incomes are higher, happiness and other components of subjective well-being may be reduced by migration. The reason for this apparent paradox that is suggested in the literature is 'adaptation theory' - that happiness depends not only on income but also on aspirations (Knight and Gunatilaka, 2010). Even though there is a rise in absolute incomes, the aspirations of migrants may have risen by even more when they observe the high incomes in their new environment, and these unmet expectations cause frustration and reduce subjective well-being. However, previous research is not able to rule out selectivity biases, whereby unhappy people are more likely to migrate.

In this paper, we use unique survey data on successful and unsuccessful applicants to a migration lottery to experimentally estimate the impact of international migration on objective and subjective well-being. Our results call into question the view that migration causes subjective well-being to fall. Instead, we find complex effects of migration, with mental health improving but happiness declining, self-rated welfare rising if viewed retrospectively but static if viewed experimentally, self-rated social respect rising retrospectively but falling experimentally, and subjective income adequacy rising. These complex changes in subjective well-being contrast with uniformly large improvements in objective measures such as incomes and expenditures. The discrepancy between retrospective and experimental estimates may reflect a filtering of past memories that makes retrospective questions about changes in subjective well-being an unreliable guide to actual changes. The overall complexity of the results we find highlights difficulties of measuring changes in subjective well-being when reference frames change, as likely occurs with migration. 


\section{REFERENCES}

Akay, A., Bargain, O., Zimmermann, K. 2012. Relative concerns of rural-to-urban migrants in China. Journal of Economic Behaviour and Organization 81(2): 421-441.

Amit, K., Litwin, H. 2010. The subjective well-being of immigrants aged 50 or older in Israel. Social Indicators Research 98(1): 89-104.

Angrist, J. 2004. Treatment effect heterogeneity in theory and practice. Economic Journal 502, C52-C83.

Angrist, J., Imbens, G., Rubin, D., 1996. Identification of causal effects using instrumental variables. Journal of the American Statistical Association 91, 444-55.

Bartram, D. 2010. International migration, open borders debates, and happiness. International Studies Review 12(3): 339-361.

Bartram, D. 2011. Economic migration and happiness: Comparing immigrants' and natives' happiness gains from income. Social Indicators Research 103(1): 57-76.

Bayram, N., Thorburn, D., Demirhan, H., Bilgel, N., 2007. Quality of life among Turkish immigrants in Sweden. Quality of Life Research 16, 1319-33.

Borraz, F., Pozo, S., Rossi, M. 2010. And what about the family back home? International migration and happiness. Journal of International Business Strategies 27(1): 7-27.

Cantril, H., 1965. The Pattern of Human Concern. Rutgers University Press, New Brunswick.

Cardenas, M., Di Maro, V., Sorkin, I. 2009. Migration and life satisfaction: evidence from Latin America. Journal of International Business Strategies 26(1): 9-33.

Clemens, M., Montenegro, C., Pritchett, L., 2008. The place premium: Wage differences for identical workers across the U.S. border. Mimeo Center for Global Development.

Deaton, A., 2008. Income, health and well-being around the world: evidence from the Gallup World Poll. Journal of Economic Perspectives 22, 53-72. 
Deaton, A., 2009. Instruments of development: Randomization in the tropics, and the search for the elusive keys to economic development. NBER Working Paper No. 14690.

Di Tella, R., Haisken-De New, J., MacCulloch, R., 2010. Happiness adaptation to income and to status in an individual panel. Journal of Economic Behavior and Organization 76(3): 834-852.

Gibson, J., McKenzie, D., Rohorua, H., 2008. How pro-poor is the selection of seasonal migrant workers from Tonga under New Zealand's Recognized Seasonal Employer (RSE) program? Pacific Economic Bulletin 23, 187-204.

Gibson, J., Stillman, S., McKenzie, D., Rohorua, H., 2013. Natural experiment evidence on the effect of migration on blood pressure and hypertension" Health Economics (forthcoming, doi: 10.1002/hec.2834).

Graham, C., 2008. Happiness and health: lessons - and questions - for public policy. Health Affairs 27, 72-87.

Graham, C., Markowitz, J. 2011. Aspirations and happiness of potential Latin American immigrants. Journal of Social Research and Policy 2(2): 9-25.

Knight, J., Gunatilaka, R., 2010. Great expectations? The subjective well-being of ruralurban migrants in China. World Development 38(1): 113-124.

Knight, J., Gunatilaka, R., 2010a. The rural-urban divide in China: Income but not happiness? Journal of Development Studies 46(3): 506-534.

Knight, J., Gunatilaka, R., 2012. Aspirations, Adaptation and Subjective Well-being of Ruralurban Migrants in China', in D. Clark (ed), Adaptation, Poverty and Development: The Dynamics of Subjective Well-Being, Palgrave Macmillan, 2012, 91-110.

Lokshin, M., Ravallion, M., 2005. Rich and powerful? Subjective power and welfare in Russia. Journal of Economic Behavior and Organization 56, 141-172. 
McKenzie, D., Gibson, J., Stillman, S., 2010. How important is selection? Experimental vs non-experimental measures of income gains from migration. Journal of the European Economic Association 8, 913-945.

McKenzie, D., Gibson, J., Stillman, S., 2013. A land of milk and honey with streets paved with gold: Do emigrants have over-optimistic expectations about incomes abroad?" Journal of Development Economics (forthcoming, doi:10.1016/j.jdeveco.2012.01.001)

Nielsen, I., Smyth, R., Zhai, Q., 2010. Subjective well-being of China's off-farm migrants. Journal of Happiness Studies 11, 315-333.

Özden, Ç., Parsons, C., Schiff, M., Walmsley, T., 2011. Where on Earth is everybody? The evolution of global bilateral migration 1960-2000. World Bank Economic Review 25(1): $12-56$.

Pritchett, L., 2006. Let Their People Come: Breaking the Gridlock on Global Labor Mobility Center for Global Development, Washington DC.

Ravallion, M., Lokshin, M., 2002. Self-rated economic welfare in Russia. European Economic Review 46, 1453-73.

Safi, M., 2009. Immigrants' life satisfaction in Europe: Between assimilation and discrimination. European Sociological Review 26, 159-176.

Spoonley, P., Didham, R. 2008. Emerging demographic and socioeconomic features of the Pacific population in New Zealand. In Pacific Interactions Bisley, A. (ed), Institute of Policy Studies, pp. 13-40.

Stillman, S., McKenzie, D., Gibson. J., 2009. Migration and mental health: evidence from a natural experiment. Journal of Health Economics 28, 677-87.

UNDP, 2009. Human Development Report, United Nations Development Program. 
Veit, C., Ware, J., 1983. The structure of psychological distress and well-being in general populations. Journal of Consulting and Clinical Psychology 51, 730-742.

World Health Organization (WHO) 2001. The World Health Report--Mental Health: New Understanding, New Hope. World Health Organization.

Zhao, Y. 1999. Leaving the countryside: Rural-to-urban migration decisions in China. American Economic Review 89, 281-286. 


\section{ENDNOTES}

\footnotetext{
${ }^{1}$ Bayram et al. (2007) measure quality of life of Turkish immigrants in Sweden, and then compare with results of an earlier study of quality of life in Turkey. But there was no attempt to match the sample from Turkey to make it a valid counterfactual for the immigrants in Sweden and no treatment for immigrant self-selectivity.

${ }^{2}$ All statistics in this section are from the 2009 Human Development Report (UNDP, 2009).

${ }^{3}$ The median migrant in the sample (described below) moved within one month of receiving their residence approval.
}

${ }^{4}$ The foreign-born share was $22.9 \%$ at the time of the 2006 Census and the Pacific ethnic group was $6.9 \%$ of the total population.

${ }^{5}$ The migrants were asked about the probability of returning to live in Tonga within the next five years, and also returning for the majority of their retirement. The average probabilities were only $0.06 \%$ and $3.48 \%$, suggesting that settlement intentions in New Zealand were very firm.

${ }^{6}$ Many of the 302 target households were unavailable for us to survey because they were reserved for possible selection into the sample of the Longitudinal Immigrant Survey fielded by Statistics New Zealand at the same time. In McKenzie et al. (2010), we describe in detail the tracking of the sample and show that we achieved a contact rate of over $70 \%$ of our potential sample. The main reasons for non-contact were incomplete name and address details, which should be independent of welfare outcomes and therefore not a source of sample selectivity bias. There was only one refusal to take part in the survey in New Zealand and none in Tonga during the first round.

${ }^{7}$ Specifically, two households were in Australia, two in the US, one in the UK, one moved back to Tonga and four moved to outer areas in New Zealand. Since the survey includes a detailed health module with anthropometric, blood pressure and respiratory measurements, telephone interviews were not possible.

${ }^{8}$ While some of these non-complier group of households do migrate to New Zealand between the first and second wave of our survey, in this paper we continue to treat them as non-compliers and hence consistently estimate the impact of migrating by wave 1 of our survey on outcomes in both wave 1 and 2 .

${ }^{9}$ The re-interview rate was lower than for the sample in New Zealand because the interview teams in Tonga were, at the same time, working on a new survey of seasonal migrants (Gibson et al., 2008) and the limited resources for the survey fieldwork meant that there was incomplete tracking of PINZMS original sample members. 
${ }^{10}$ The PPP exchange rates for Tonga from sources such as the World Bank are extrapolations from other countries rather than being based on directly collected prices and these extrapolations do not appear to be reliable.

${ }^{11}$ We use version 2, which is the mental health component of the 36 item short-form health survey (SF-36) which has been used in over 50 countries as part of the International Quality of Life Assessment project (http://www.sf-36.org).

${ }^{12}$ Although the wording is identical to the survey used by Lokshin and Ravallion (2005), their ladder had only nine steps while ours has ten.

${ }^{13}$ Another threat to the validity of results using the lottery comes from multiple entries; individuals can decide each year whether or not to enter the PAC ballot, with those entering more often having greater chance of a winning ballot. If multiple entrants differ from other ballot entrants, the results still may be subject to a form of selection bias. In previous work, we have shown that controlling for multiple entries as best possible with the available data from the PINZMS makes no difference to the estimated treatment effects (Gibson et al., 2013).

${ }^{14}$ Since the dependent variable is in logs, the proportionate change is $\left[\exp \left(\beta_{j}\right)-1\right]$ and $[\exp (0.747)-1]=1.11$.

${ }^{15}$ With only a single question it is impossible to estimate the internal consistency of the subjective well-being indicator and to capture the multidimensionality of psychological constructs (Nielsen et al., 2010, p. 318). Moreover, Deaton (2008, p.70) points out that neither life satisfaction nor health satisfaction can be taken as reliable indicators of population well-being since neither adequately reflects objective conditions of health. 
Table 1: Test for Randomisation

Comparison of Ex-ante characteristics of principal applicants in successful and unsuccessful ballots

\begin{tabular}{|c|c|c|c|c|c|c|c|c|c|}
\hline & \multicolumn{2}{|c|}{$\begin{array}{l}\text { Sample Means } \\
\text { Wave } 1\end{array}$} & \multirow{2}{*}{$\begin{array}{c}\text { T-test } \\
\text { of equality } \\
\text { of means } \\
\text { p-value }\end{array}$} & \multicolumn{2}{|c|}{$\begin{array}{l}\text { Sample Means } \\
\text { Wave } 2\end{array}$} & \multirow{2}{*}{$\begin{array}{c}\text { T-test } \\
\text { of equality } \\
\text { of means } \\
\text { p-value }\end{array}$} & \multicolumn{2}{|c|}{$\begin{array}{c}\text { Sample Means } \\
\text { Wave } 1 \text { Balanced Panel }\end{array}$} & \multirow{2}{*}{$\begin{array}{c}\text { T-test } \\
\text { of equality } \\
\text { of means } \\
\text { p-value }\end{array}$} \\
\hline & $\begin{array}{c}\text { Successful } \\
\text { Ballots }\end{array}$ & $\begin{array}{c}\text { Unsuccessful } \\
\text { Ballots }\end{array}$ & & $\begin{array}{c}\text { Successful } \\
\text { Ballots }\end{array}$ & $\begin{array}{c}\text { Unsuccessful } \\
\text { Ballots }\end{array}$ & & $\begin{array}{c}\text { Successful } \\
\text { Ballots } \\
\end{array}$ & $\begin{array}{c}\text { Unsuccessful } \\
\text { Ballots } \\
\end{array}$ & \\
\hline Proportion female & 0.40 & 0.48 & 0.19 & 0.37 & 0.40 & 0.68 & 0.37 & 0.41 & 0.65 \\
\hline Proportion who are married & 0.68 & 0.68 & 0.99 & 0.73 & 0.74 & 0.81 & 0.72 & 0.77 & 0.45 \\
\hline Age & 34.3 & 33.7 & 0.46 & 37.1 & 36.1 & 0.41 & 34.7 & 34.8 & 0.92 \\
\hline Years of schooling & 12.1 & 11.9 & 0.47 & 10.7 & 10.9 & 0.66 & 12.0 & 11.7 & 0.93 \\
\hline Proportion born on Tongatapu & 0.75 & 0.78 & 0.54 & 0.75 & 0.83 & 0.18 & 0.75 & 0.82 & 0.25 \\
\hline Height & 171.7 & 168.9 & 0.13 & 173.6 & 170.8 & 0.02 & 171.9 & 167.4 & 0.05 \\
\hline Proportion Catholic & 0.14 & 0.13 & 0.75 & 0.14 & 0.13 & 0.86 & 0.14 & 0.13 & 0.89 \\
\hline Proportion Mormon & 0.14 & 0.13 & 0.79 & 0.09 & 0.10 & 0.86 & 0.17 & 0.11 & 0.68 \\
\hline Prior Employment (before moving) & 0.81 & 0.57 & 0.00 & 0.78 & 0.52 & 0.00 & 0.85 & 0.61 & 0.00 \\
\hline Prior Income (before moving) & 93.7 & 83.0 & 0.36 & 90.1 & 69.7 & 0.11 & 97.4 & 83.8 & 0.35 \\
\hline Prior HH Income (before moving) & 127.1 & 152.5 & 0.19 & 117.5 & 128.0 & 0.62 & 130.1 & 154.0 & 0.34 \\
\hline Proportion visit NZ before 2000 & 0.44 & 0.29 & 0.01 & 0.42 & 0.31 & 0.12 & 0.46 & 0.34 & 0.15 \\
\hline Proportion in New Zealand & 0.82 & & & 0.85 & & & 0.89 & & \\
\hline Total Sample Size & 130 & 124 & & 110 & 75 & & 99 & 61 & \\
\hline
\end{tabular}

Note: Test statistics account for clustering at the household level. 
Table 2: Impact of Migration on Objective Measures of Welfare

\begin{tabular}{|c|c|c|c|c|c|c|c|c|c|}
\hline & $\begin{array}{c}\text { PA Weekly } \\
\text { Wage }\end{array}$ & $\begin{array}{l}\text { Log Household } \\
\text { Income }\end{array}$ & $\begin{array}{l}\text { Log Household } \\
\text { Income PC }\end{array}$ & $\begin{array}{c}\text { PA Weekly } \\
\text { Wage }\end{array}$ & $\begin{array}{l}\text { Log Household } \\
\text { Income }\end{array}$ & $\begin{array}{l}\text { Log Household } \\
\text { Income PC }\end{array}$ & $\begin{array}{l}\text { Log Household } \\
\text { Expend }\end{array}$ & $\begin{array}{l}\text { Log Household } \\
\text { Expend PC }\end{array}$ & $\begin{array}{c}\text { Food/Total } \\
\text { Expend Ratio }\end{array}$ \\
\hline & & Wave 1 & & \multicolumn{6}{|c|}{ Wave 2} \\
\hline Mean Unsuccessful & 117.4 & 9.59 & 8.14 & 105.4 & 9.31 & 7.79 & 8.98 & 7.46 & 0.806 \\
\hline No Controls & $\begin{array}{c}321.0 * * * \\
(33.6)\end{array}$ & $\begin{array}{c}0.747 * * * \\
(0.115)\end{array}$ & $\begin{array}{c}0.478 * * * \\
(0.125)\end{array}$ & $\begin{array}{c}406.0 * * * \\
(36.0)\end{array}$ & $\begin{array}{c}1.539 * * * \\
(0.129)\end{array}$ & $\begin{array}{c}1.618 * * * \\
(0.136)\end{array}$ & $\begin{array}{c}1.197 * * * \\
(0.097)\end{array}$ & $\begin{array}{c}1.277 * * * \\
(0.108)\end{array}$ & $\begin{array}{c}-0.480^{* * *} \\
(0.024)\end{array}$ \\
\hline R-squared & 0.238 & 0.042 & 0.012 & 0.284 & 0.192 & 0.186 & 0.229 & 0.196 & 0.436 \\
\hline Observations & 253 & 246 & 246 & 184 & 185 & 185 & 185 & 185 & 185 \\
\hline Full Controls & $\begin{array}{c}308.0 * * * \\
(33.5)\end{array}$ & $\begin{array}{c}0.705 * * * \\
(0.096)\end{array}$ & $\begin{array}{c}0.375^{* * *} \\
(0.126)\end{array}$ & $\begin{array}{c}367.0 * * * \\
(31.6)\end{array}$ & $\begin{array}{c}1.404 * * * \\
(0.124)\end{array}$ & $\begin{array}{c}1.464 * * * \\
(0.139)\end{array}$ & $\begin{array}{c}1.156 * * * \\
(0.115)\end{array}$ & $\begin{array}{c}1.215^{* * * *} \\
(0.126)\end{array}$ & $\begin{array}{c}-0.479 * * * \\
(0.021)\end{array}$ \\
\hline R-squared & 0.491 & 0.492 & 0.368 & 0.544 & 0.546 & 0.437 & 0.420 & 0.346 & 0.626 \\
\hline Observations & 248 & 242 & 242 & 166 & 167 & 167 & 167 & 167 & 167 \\
\hline PA Balanced Panel & $\begin{array}{c}293.0 * * * \\
(33.4)\end{array}$ & $\begin{array}{c}0.651 * * * \\
(0.111)\end{array}$ & $\begin{array}{c}0.454 * * * \\
(0.149)\end{array}$ & $\begin{array}{c}363.4 * * * \\
(33.6)\end{array}$ & $\begin{array}{c}1.380 * * * \\
(0.123)\end{array}$ & $\begin{array}{c}1.481 * * * \\
(0.147)\end{array}$ & $\begin{array}{c}1.145^{* * * *} \\
(0.118)\end{array}$ & $\begin{array}{c}1.246^{* * * *} \\
(0.130)\end{array}$ & $\begin{array}{c}-0.478 * * * \\
(0.022)\end{array}$ \\
\hline R-squared & 0.607 & 0.61 & 0.432 & 0.543 & 0.587 & 0.451 & 0.484 & 0.411 & 0.671 \\
\hline Observations & 157 & 152 & 152 & 157 & 158 & 158 & 158 & 158 & 158 \\
\hline
\end{tabular}

Note: All values are in June 2006 NZD. Full controls are listed in Table 1. Standard Errors are Huber/White; ***, **,* denote statistical significance at 1\%, 5\% and 10\% level. 
Table 3: Impact of Migration on Subjective Measures of Welfare

\begin{tabular}{|c|c|c|c|c|c|c|c|}
\hline & $\begin{array}{r}\text { Happiness } \\
5) \\
\end{array}$ & $\begin{array}{cc}\text { (1- } & \text { Residual Mental } \\
\text { Health }(4-20)\end{array}$ & $\begin{array}{l}\text { Happiness } \\
(1-5) \\
\end{array}$ & $\begin{array}{c}\text { Residual Mental } \\
\text { Health (4-20) }\end{array}$ & $\begin{array}{c}\text { Current Welfare } \\
\text { Ladder }(1-10)\end{array}$ & $\begin{array}{l}\text { Current Respect } \\
\text { Ladder (1-10) }\end{array}$ & $\begin{array}{c}\text { Income Adequacy } \\
(1-4)\end{array}$ \\
\hline & \multicolumn{2}{|r|}{ Wave 1} & \multicolumn{5}{|c|}{ Wave 2} \\
\hline Mean Unsuccessful & 4.14 & 15.03 & 4.33 & 12.54 & 6.13 & 6.76 & 2.21 \\
\hline No Controls & $\begin{array}{l}-0.128 \\
(0.082)\end{array}$ & $\begin{array}{c}1.783 * * * \\
(0.257)\end{array}$ & $\begin{array}{c}-0.669^{* * *} \\
(0.111)\end{array}$ & $\begin{array}{l}3.171 * * * \\
(0.4)\end{array}$ & $\begin{array}{c}0.040 \\
(0.149)\end{array}$ & $\begin{array}{c}-0.937 * * * \\
(0.194)\end{array}$ & $\begin{array}{l}0.252 * * \\
(0.109)\end{array}$ \\
\hline R-squared & 0.002 & 0.049 & 0.055 & 0.076 & 0.000 & 0.030 & 0.012 \\
\hline Observations & 253 & 253 & 182 & 181 & 185 & 185 & 185 \\
\hline Full Controls & $\begin{array}{l}-0.152 \\
(0.105)\end{array}$ & $\begin{array}{l}1.769 * * * \\
(0.294)\end{array}$ & $\begin{array}{c}-0.778 * * * \\
(0.125)\end{array}$ & $\begin{array}{l}2.961 * * * \\
(0.5)\end{array}$ & $\begin{array}{c}0.140 \\
(0.186)\end{array}$ & $\begin{array}{c}-0.829 * * * \\
(0.242)\end{array}$ & $\begin{array}{l}0.246^{* *} \\
(0.110)\end{array}$ \\
\hline R-squared & 0.159 & 0.249 & 0.315 & 0.248 & 0.261 & 0.351 & 0.329 \\
\hline Observations & 248 & 248 & 164 & 163 & 167 & 167 & 167 \\
\hline PA Balanced Panel & $\begin{array}{l}-0.011 \\
(0.134)\end{array}$ & $\begin{array}{l}1.870 * * * \\
(0.302)\end{array}$ & $\begin{array}{c}-0.803 * * * \\
(0.127)\end{array}$ & $\begin{array}{l}2.858 * * * \\
(0.6)\end{array}$ & $\begin{array}{c}0.061 \\
(0.195)\end{array}$ & $\begin{array}{c}-0.901 * * * \\
(0.259)\end{array}$ & $\begin{array}{l}0.200 * \\
(0.111)\end{array}$ \\
\hline R-squared & 0.34 & 0.38 & 0.362 & 0.236 & 0.248 & 0.339 & 0.354 \\
\hline Observations & 158 & 158 & 155 & 154 & 158 & 158 & 158 \\
\hline
\end{tabular}

Note: Full controls are listed in Table 1. Standard Errors are Huber/White; ***, **, * denote statistical significance at $1 \%, 5 \%$ and $10 \%$ level. 
Table 4: Change in Subjective Welfare Based on Comparison With Retrospective Report

\begin{tabular}{|c|c|c|c|c|c|c|}
\hline & \multicolumn{3}{|c|}{ Welfare Ladder } & \multicolumn{3}{|c|}{ Respect Ladder } \\
\hline & Pooled & Men & Women & Pooled & Men & Women \\
\hline Mean Change for Men & $\begin{array}{c}0.758 * * * \\
(0.147)\end{array}$ & $\begin{array}{c}0.684 * * \\
(0.313)\end{array}$ & & $\begin{array}{c}0.667 * * * \\
(0.132)\end{array}$ & $\begin{array}{c}0.499 * * \\
(0.227)\end{array}$ & \\
\hline Mean Change for Women & $\begin{array}{c}0.688 * * * \\
(0.212)\end{array}$ & & $\begin{array}{c}0.238 \\
(0.419)\end{array}$ & $\begin{array}{c}0.156 \\
(0.179)\end{array}$ & & $\begin{array}{c}-0.745 * * \\
(0.317)\end{array}$ \\
\hline Change in Employment Status & & $\begin{array}{c}0.704 * * \\
(0.281)\end{array}$ & $\begin{array}{l}-0.080 \\
(0.553)\end{array}$ & & $\begin{array}{c}0.313 \\
(0.257)\end{array}$ & $\begin{array}{c}-0.784 \\
(0.483)\end{array}$ \\
\hline Change in Weekly Wage (100 NZD) & & $\begin{array}{l}-0.022 \\
(0.069) \\
\end{array}$ & $\begin{array}{c}0.167 \\
(0.143) \\
\end{array}$ & & $\begin{array}{c}0.018 \\
(0.052) \\
\end{array}$ & $\begin{array}{c}0.306^{* * * *} \\
(0.089)\end{array}$ \\
\hline R-squared & 0.279 & 0.082 & 0.110 & 0.220 & 0.027 & 0.289 \\
\hline Observations & 98 & 66 & 32 & 98 & 66 & 32 \\
\hline
\end{tabular}


Table 5: Explaining Subjective Measures of Welfare in Tonga

\begin{tabular}{|c|c|c|c|c|c|c|c|}
\hline & $\begin{array}{l}\text { Happiness } \\
\quad(1-5)\end{array}$ & $\begin{array}{c}\text { Residual Mental } \\
\text { Health (4-20) }\end{array}$ & $\begin{array}{c}\text { Current Welfare } \\
\text { Ladder }(1-10)\end{array}$ & $\begin{array}{l}\text { Current Respect } \\
\text { Ladder (1-10) }\end{array}$ & $\begin{array}{c}\text { Income } \\
\text { Adequacy (1-4) }\end{array}$ & $\begin{array}{c}\text { Happiness } \\
(1-5)\end{array}$ & $\begin{array}{c}\text { Residual Mental } \\
\text { Health (4-20) }\end{array}$ \\
\hline & \multicolumn{5}{|c|}{ Pooled Cross-sectional } & \multicolumn{2}{|c|}{ Individual Fixed Effects } \\
\hline Female & $\begin{array}{c}-0.172 * * \\
(0.072)\end{array}$ & $\begin{array}{c}0.609 * * * \\
(0.233)\end{array}$ & $\begin{array}{l}-0.175 \\
(0.183)\end{array}$ & $\begin{array}{l}-0.193 \\
(0.215)\end{array}$ & $\begin{array}{c}0.014 \\
(0.128)\end{array}$ & & \\
\hline Married & $\begin{array}{c}0.047 \\
(0.082)\end{array}$ & $\begin{array}{l}-0.478 \\
(0.305)\end{array}$ & $\begin{array}{l}-0.060 \\
(0.205)\end{array}$ & $\begin{array}{l}-0.272 \\
(0.217)\end{array}$ & $\begin{array}{c}0.073 \\
(0.140)\end{array}$ & & \\
\hline Age & $\begin{array}{c}0.005 \\
(0.006)\end{array}$ & $\begin{array}{l}-0.001 \\
(0.020)\end{array}$ & $\begin{array}{c}0.017 \\
(0.011)\end{array}$ & $\begin{array}{c}0.021 \\
(0.015)\end{array}$ & $\begin{array}{c}0.003 \\
(0.009)\end{array}$ & $\begin{array}{c}0.000 \\
(0.078)\end{array}$ & $\begin{array}{c}0.152 \\
(0.315)\end{array}$ \\
\hline Years of Education & $\begin{array}{c}0.004 \\
(0.019)\end{array}$ & $\begin{array}{l}-0.040 \\
(0.060)\end{array}$ & $\begin{array}{c}0.067 \\
(0.058)\end{array}$ & $\begin{array}{c}0.101 \\
(0.064)\end{array}$ & $\begin{array}{c}0.008 \\
(0.032)\end{array}$ & $\begin{array}{c}0.006 \\
(0.060)\end{array}$ & $\begin{array}{c}0.056 \\
(0.140)\end{array}$ \\
\hline Born Tongatapu & $\begin{array}{l}-0.049 \\
(0.077)\end{array}$ & $\begin{array}{c}-1.124 * * * \\
(0.323)\end{array}$ & $\begin{array}{c}-0.552 * * \\
(0.258)\end{array}$ & $\begin{array}{c}-1.042 * * * \\
(0.290)\end{array}$ & $\begin{array}{l}-0.131 \\
(0.178)\end{array}$ & & \\
\hline Catholic & $\begin{array}{c}0.042 \\
(0.095)\end{array}$ & $\begin{array}{c}0.260 \\
(0.370)\end{array}$ & $\begin{array}{c}0.117 \\
(0.221)\end{array}$ & $\begin{array}{c}0.055 \\
(0.270)\end{array}$ & $\begin{array}{l}-0.074 \\
(0.163)\end{array}$ & & \\
\hline Mormon & $\begin{array}{c}0.011 \\
(0.108)\end{array}$ & $\begin{array}{l}-0.124 \\
(0.369)\end{array}$ & $\begin{array}{l}-0.044 \\
(0.209)\end{array}$ & $\begin{array}{l}-0.091 \\
(0.340)\end{array}$ & $\begin{array}{l}-0.064 \\
(0.174)\end{array}$ & & \\
\hline Visited NZ Before 2000 & $\begin{array}{c}0.077 \\
(0.068)\end{array}$ & $\begin{array}{c}0.563 * * \\
(0.240)\end{array}$ & $\begin{array}{c}0.030 \\
(0.195)\end{array}$ & $\begin{array}{c}0.320 \\
(0.245)\end{array}$ & $\begin{array}{c}0.140 \\
(0.149)\end{array}$ & & \\
\hline Employed & $\begin{array}{l}-0.231 \\
(0.217)\end{array}$ & $\begin{array}{l}1.442 * * \\
(0.718)\end{array}$ & $\begin{array}{c}0.200 \\
(0.844)\end{array}$ & $\begin{array}{l}-0.096 \\
(0.958)\end{array}$ & $\begin{array}{l}-0.963 \\
(0.610)\end{array}$ & $\begin{array}{c}0.277 \\
(0.414)\end{array}$ & $\begin{array}{c}2.204 \\
(1.986)\end{array}$ \\
\hline Weekly Wage (100 NZD) & $\begin{array}{l}-0.044 \\
(0.057)\end{array}$ & $\begin{array}{c}0.213 \\
(0.194)\end{array}$ & $\begin{array}{c}0.484 * * * \\
(0.078)\end{array}$ & $\begin{array}{c}0.473 * * * \\
(0.084)\end{array}$ & $\begin{array}{c}0.029 \\
(0.058)\end{array}$ & $\begin{array}{c}-0.018 \\
(0.054)\end{array}$ & $\begin{array}{l}-0.002 \\
(0.225)\end{array}$ \\
\hline $\begin{array}{l}\text { Percentile in Tongan PINZMS } \\
\text { Weekly Wage Distribution }\end{array}$ & $\begin{array}{c}0.00986^{* *} \\
(0.005)\end{array}$ & $\begin{array}{c}-0.0341^{*} \\
(0.018)\end{array}$ & $\begin{array}{l}-0.015 \\
(0.018)\end{array}$ & $\begin{array}{l}-0.007 \\
(0.020)\end{array}$ & $\begin{array}{c}0.021 \\
(0.014)\end{array}$ & $\begin{array}{l}-0.005 \\
(0.009)\end{array}$ & $\begin{array}{l}-0.031 \\
(0.044)\end{array}$ \\
\hline $\begin{array}{l}\text { R-squared } \\
\text { Individuals } \\
\text { Observations }\end{array}$ & 0.126 & 0.363 & 0.210 & 0.297 & $\begin{array}{c}0.142 \\
146\end{array}$ & $\begin{array}{c}0.156 \\
135 \\
265\end{array}$ & $\begin{array}{c}0.471 \\
135 \\
264\end{array}$ \\
\hline
\end{tabular}

Note: Outcomes are responses by principal applicants or pseudo-principal applicants in non-applicant households. Standard Errors are Huber/White and allow for individual correlation over time; $* * * * *, *$ denote statistical significance at $1 \%, 5 \%$ and $10 \%$ level. The regressions also control for the year of observation and whether the survey occured during Dec/Jan. 
Table 6: Explaining Subjective Measures of Welfare in New Zealand

\begin{tabular}{|c|c|c|c|c|c|c|c|}
\hline & $\begin{array}{l}\text { Happiness } \\
(1-5)\end{array}$ & $\begin{array}{c}\text { Residual Mental } \\
\text { Health (4-20) }\end{array}$ & $\begin{array}{l}\text { Current Welfare } \\
\text { Ladder (1-10) }\end{array}$ & $\begin{array}{l}\text { Current Respect } \\
\text { Ladder }(1-10)\end{array}$ & $\begin{array}{c}\text { Income } \\
\text { Adequacy (1-4) }\end{array}$ & $\begin{array}{l}\text { Happiness } \\
\quad(1-5)\end{array}$ & $\begin{array}{l}\text { Residual Mental } \\
\text { Health (4-20) }\end{array}$ \\
\hline & \multicolumn{5}{|c|}{ Pooled Cross-sectional } & \multicolumn{2}{|c|}{ Individual Fixed Effects } \\
\hline Female & $\begin{array}{c}0.098 \\
(0.078)\end{array}$ & $\begin{array}{c}0.355 \\
(0.282)\end{array}$ & $\begin{array}{c}0.020 \\
(0.187)\end{array}$ & $\begin{array}{c}0.005 \\
(0.209)\end{array}$ & $\begin{array}{c}0.100 \\
(0.172)\end{array}$ & & \\
\hline Married & $\begin{array}{l}-0.007 \\
(0.098)\end{array}$ & $\begin{array}{l}-0.061 \\
(0.299)\end{array}$ & $\begin{array}{l}-0.261 \\
(0.200)\end{array}$ & $\begin{array}{l}-0.094 \\
(0.197)\end{array}$ & $\begin{array}{l}-0.158 \\
(0.183)\end{array}$ & & \\
\hline Age & $\begin{array}{l}-0.001 \\
(0.005)\end{array}$ & $\begin{array}{c}-0.0460 * * * \\
(0.016)\end{array}$ & $\begin{array}{c}0.000 \\
(0.010)\end{array}$ & $\begin{array}{c}0.0275^{* *} \\
(0.013)\end{array}$ & $\begin{array}{l}0.0189 * \\
(0.010)\end{array}$ & $\begin{array}{l}-0.046 \\
(0.059)\end{array}$ & $\begin{array}{l}-0.086 \\
(0.155)\end{array}$ \\
\hline Years of Education & $\begin{array}{c}0.007 \\
(0.014)\end{array}$ & $\begin{array}{c}0.050 \\
(0.037)\end{array}$ & $\begin{array}{c}0.0435 * \\
(0.026)\end{array}$ & $\begin{array}{l}-0.015 \\
(0.032)\end{array}$ & $\begin{array}{l}-0.025 \\
(0.022)\end{array}$ & $\begin{array}{c}0.010 \\
(0.021)\end{array}$ & $\begin{array}{c}0.069 \\
(0.069)\end{array}$ \\
\hline Born Tongatapu & $\begin{array}{l}-0.005 \\
(0.069)\end{array}$ & $\begin{array}{l}-0.223 \\
(0.181)\end{array}$ & $\begin{array}{l}-0.142 \\
(0.160)\end{array}$ & $\begin{array}{c}0.172 \\
(0.167)\end{array}$ & $\begin{array}{c}0.114 \\
(0.139)\end{array}$ & & \\
\hline Catholic & $\begin{array}{c}0.054 \\
(0.113)\end{array}$ & $\begin{array}{c}0.021 \\
(0.293)\end{array}$ & $\begin{array}{l}-0.011 \\
(0.236)\end{array}$ & $\begin{array}{c}0.111 \\
(0.338)\end{array}$ & $\begin{array}{c}0.141 \\
(0.166)\end{array}$ & $\begin{array}{c}0.195 \\
(0.240)\end{array}$ & $\begin{array}{c}0.298 \\
(0.611)\end{array}$ \\
\hline Mormon & $\begin{array}{c}0.258 * * * \\
(0.084)\end{array}$ & $\begin{array}{c}0.239 \\
(0.301)\end{array}$ & $\begin{array}{l}-0.185 \\
(0.326)\end{array}$ & $\begin{array}{c}0.134 \\
(0.274)\end{array}$ & $\begin{array}{l}-0.095 \\
(0.195)\end{array}$ & $\begin{array}{l}0.516^{*} \\
(0.272)\end{array}$ & $\begin{array}{l}1.230^{*} \\
(0.738)\end{array}$ \\
\hline Visited NZ Before 2000 & $\begin{array}{l}-0.043 \\
(0.080)\end{array}$ & $\begin{array}{l}-0.113 \\
(0.196)\end{array}$ & $\begin{array}{l}0.271 * \\
(0.153)\end{array}$ & $\begin{array}{c}0.104 \\
(0.199)\end{array}$ & $\begin{array}{c}0.102 \\
(0.138)\end{array}$ & & \\
\hline Employed & $\begin{array}{c}0.030 \\
(0.151)\end{array}$ & $\begin{array}{c}-1.189 * * * \\
(0.309)\end{array}$ & $\begin{array}{c}0.113 \\
(0.290)\end{array}$ & $\begin{array}{l}-0.501 \\
(0.440)\end{array}$ & $\begin{array}{l}-0.318 \\
(0.309)\end{array}$ & $\begin{array}{c}0.215 \\
(0.292)\end{array}$ & $\begin{array}{c}-1.386 * * \\
(0.663)\end{array}$ \\
\hline Weekly Wage (100 NZD) & $\begin{array}{l}-0.010 \\
(0.021)\end{array}$ & $\begin{array}{c}0.065 \\
(0.086)\end{array}$ & $\begin{array}{l}-0.003 \\
(0.060)\end{array}$ & $\begin{array}{c}0.159 \\
(0.134)\end{array}$ & $\begin{array}{c}0.280 * * * \\
(0.061)\end{array}$ & $\begin{array}{l}-0.036 \\
(0.069)\end{array}$ & $\begin{array}{c}0.149 \\
(0.135)\end{array}$ \\
\hline $\begin{array}{l}\text { Percentile in NZ PI Migrant } \\
\text { Weekly Wage Distribution }\end{array}$ & $\begin{array}{c}0.001 \\
(0.004) \\
\end{array}$ & $\begin{array}{c}0.008 \\
(0.012) \\
\end{array}$ & $\begin{array}{c}0.009 \\
(0.010) \\
\end{array}$ & $\begin{array}{l}-0.006 \\
(0.015) \\
\end{array}$ & $\begin{array}{c}-0.0282 * * * \\
(0.010) \\
\end{array}$ & $\begin{array}{c}0.001 \\
(0.009) \\
\end{array}$ & $\begin{array}{r}0.002 \\
(0.024) \\
\end{array}$ \\
\hline $\begin{array}{l}\text { R-squared } \\
\text { Individuals }\end{array}$ & 0.238 & 0.433 & 0.191 & 0.182 & 0.173 & $\begin{array}{c}0.359 \\
85\end{array}$ & $\begin{array}{c}0.495 \\
85\end{array}$ \\
\hline Observations & 186 & 186 & 87 & 87 & 87 & 168 & 168 \\
\hline
\end{tabular}

